\title{
Digital PCR provides sensitive and absolute calibration for high throughput sequencing
}

Richard A White III ${ }^{\dagger}$, Paul C Blainey ${ }^{\dagger}$, H Christina Fan and Stephen R Quake*

Address: Department of Bioengineering at Stanford University and Howard Hughes Medical Institute, Stanford, California 94305, USA

Email: Richard A White - raw937@sbcglobal.net; Paul C Blainey - blainey@stanford.edu; H Christina Fan - chfan@stanford.edu;

Stephen R Quake* - quake@stanford.edu

* Corresponding author †Equal contributors

Published: 19 November 2009

BMC Genomics 2009, 10:54| doi:10.1 |86/|47|-2|64-10-54|

This article is available from: http://www.biomedcentral.com/I47I-2/64/I0/54I

(C) 2009 White et al; licensee BioMed Central Ltd.

This is an Open Access article distributed under the terms of the Creative Commons Attribution License (http://creativecommons.org/licenses/by/2.0), which permits unrestricted use, distribution, and reproduction in any medium, provided the original work is properly cited.

\section{Correction}

After this article [1] appeared online, an error was called to our attention. The "universal probe" sequence UPL \#149 in Table 6 appears with the $5^{\prime}$ and 3 ' ends reversed. The correct sequence of this locked nucleic acid (LNA) probe is 5'-TCGCCGCC-3'. This typographical error does not affect any of the conclusions drawn in the article.

\section{References}

I. White RA, Blainey PC, Fan HC, Quake SR: Digital PCR provides sensitive and absolute calibration for high throughput sequencing. BMC Genomics 2009, 10:116. 